\title{
Physiological responses of Coffea arabica cultivars in association with arbuscular mycorrhizal fungi
}

\author{
Rafaele de Sousa Cruz' ${ }^{\text {(D) }}$, Fausto Henrique Vieira Araújo1 (iD), André Cabral França1 (D), \\ Levy Tadin Sardinha' ${ }^{1}$, Caroline Maira Miranda Machado ${ }^{1}$ (D)
}

${ }^{1}$ Universidade Federal dos Vales do Jequitinhonha e Mucuri/ UFVJM, Faculdade de Ciências Agrárias, Departamento de Agronomia, Diamantina, MG, Brasil Contact authors: rafaelesousacruz@outlook.com, faustonura@gmail.com, carolmaira40@gmail.com, cabralfranca@yahoo.com.br

Received in October 15, 2019 and approved in March 15, 2020

\begin{abstract}
The inoculation of coffee plants with arbuscular mycorrhizal fungi (AMF) may influence some of its physiological parameters, promoting benefits in the growth of newly planted coffee. The objective of this work was to evaluate the physiological responses of different cultivars of Coffea arabica inoculated with arbuscular mycorrhizal fungi. The experiment was conducted in a vegetation house in Diamantina, state Minas Gerais. The design was in randomized blocks, in a $3 \times 4$ factorial scheme, with four replications. The factors were composed of coffee seedlings of Rubi (MG 1192), Mundo Novo (IAC 379-19) and Catuaí Vermelho (IAC 144) cultivars, inoculated or not with FMA Rhizophagus clarus, Acaulospora colombiana and Mix composed by R. clarus and A. colombiana. At 150 days after transplantation, physiological characteristics such as photosynthetic rate, internal carbon concentration, stomatal conductance, transpiration rate, water use efficiency, internal carbon / atmospheric carbon ratio and percentage of mycorrhizal colonization were evaluated. AMF inoculation affected positively the physiology of coffee plants, increasing photosynthetic rate (A), stomatal conductance (Gs), transpiration, carbon consumed $\left(\Delta \mathrm{CO}_{2}\right)$, water use efficiency (EUA) and percentage of mycorrhizal colonization (\%), as well as reducing the internal carbon concentration (Ci) for all combinations of AMF cultivars and species. The cultivar Rubi, when inoculated with $R$. clarus or Mix, obtained a higher percentage of colonization. The physiological activity of coffee plants is altered by symbiotic association, and their responses varied between AMF species and cultivars.
\end{abstract}

Key words: Coffee; Mycorrhiza; Photosynthesis; Plant growth.

\section{INTRODUCTION}

Arbuscular mycorrhizal fungi (AMF) are symbiotic associations that form with the roots of most plants, contributing to increased nutrient uptake, especially phosphorus $(\mathrm{P})$, with consequent increase in plant growth Machineski et al. (2018). Other important effects of AMFs are increased resistance of plants to attack by root system pathogens Sousa et al. (2010), Mustafa et al. (2016), Pinheiro, Souza and Coimbra (2014), and higher water absorption capacity Moreira et al. (2018).

AMF are found in about $90 \%$ of vascular plant species Heijden et al. (2015), including coffee (Coffea arabica). Through this association, plants provide carbohydrates from photosynthesis to fungi, receiving in return greater absorption of water and nutrients, especially poorly mobile soil, such as $\mathrm{P}$ and $\mathrm{Z}$, due to greater absorption surface by root system extension Zhao et al. (2015). In addition to nutritional benefits, there are reports that mycorrhizal plants have higher stomatal conductance, photosynthetic rate and antioxidant enzyme activity (Augé; Toler; Saxton, 2015; Mirshad; Puthur, 2017).

For the species $C$. arabica, studies show several benefits, such as higher growth under water stress Moreira et al. (2018), higher efficiency in P absorption Mustafa et al. (2016), higher dry mass accumulation and higher weed competitiveness França et al. (2016); Moreira et al. (2018). However, the effects of AMF are very complex and vary with the environment, plant species and fungal species Zhou et al. (2015).
The success of a crop depends, among other factors, on the choice of the appropriate variety, in which it must have desirable characteristics according to the edaphoclimatic condition, spacing and technical needs. In the main coffee regions of Minas Gerais State, there is a predominance of the cultivars Catuaí and Mundo Novo, due to their high vegetative vigor, high productive potential and good drink quality. The cultivar Rubi MG 1192 also stands out in the state for presenting in addition to these characteristics, wide adaptation in various regions of the state of Minas Gerais Pedro et al. (2011).

There may be some compatibility between AMF species and coffee genotypes, so that one species can promote better growth over another (Siqueira; Colozzi Filho, 1986; Bagyaraj; Sharma; Maiti, 2015. These variations of results may be associated with either the intrinsic characteristics of the fungus or its germination capacity or the physiological or genetic characteristics of the host.

With the aim of obtaining references that can improve the performance of seedlings previously inoculated with arbuscular mycorrhizal fungi in the field, this study aimed to evaluate the physiological responses of coffee resulting from the combination of different cultivars and species of arbuscular mycorrhizal fungi.

\section{MATERIAL AND METHODS}

The experiment was conducted from October 2017 to October 2018 in a vegetation house at the Federal University 
of Jequitinhonha and Mucuri Valleys - UFVJM in Diamantina, state Minas Gerais, Brazil, with geographic coordinates of $18^{\circ} 12$ ' $10.72^{\prime}$ 'South Latitude; $43^{\circ} 34$ '21.00' 'West longitude and elevation of $1,404 \mathrm{~m}$. The average temperature during the experimental period was $24{ }^{\circ} \mathrm{C}$ to $28^{\circ} \mathrm{C}$.

A randomized complete block design was used, with the treatments established in a $3 \times 4$ factorial scheme. The cultivars Rubi (MG 1192), Mundo Novo (IAC 379-19) and Catuaí Vermelho (IAC 144) from Coffea arabica were inoculated with AMF Rhizophagus clarus, Acaulospora colombiana or simultaneously by the two (Mix) plus the uninoculated control, with four replicates. The experimental unit consisted of a $100 \mathrm{~mm}$ diameter and $30 \mathrm{~cm}$ high polyvinyl chloride (PVC) column coffee plant.

The coffee cultivars used were obtained from the UFVJM coffee sector. The inoculants used in this study were produced by multiplication of AMF in cultivation vessels composed of sand, expanded clay, root fragments and spores of Acaulospora colombiana - SCT115A containing 33 spores/g of soil and Rhizophagus clarus RJN102A containing 22 spores/g of soil, donated by Professor Sidney Stürmer, responsible for the International Glomeromycota Culture Collection at the Regional University of Blumenau, with geographic coordinates of $26^{\circ} 55$ ' 08 'South Latitude; 49 03' 57” West Longitude and $21 \mathrm{~m}$ altitude. To quantify the spore density, samples containing $50 \mathrm{~g}$ of the inoculum were subjected to wet sieving technique, followed by centrifugation in water for three minutes at 3000 RPM, and in 50\% sucrose for two minutes at 2000 RPM, and subsequently performed. counting with the aid of a magnifying glass Gerdemann and Nicolson (1963).

The substrate used in the production of the seedlings was the mixture of a dystrophic Red-Yellow Latosol (LVd) Embrapa (2006), collected in the 0-0, $20 \mathrm{~m}$ layer, sieved in non-sterile $4 \mathrm{~mm}$ mesh and commercial Bioplant ${ }^{\circledR}$ substrate in proportion 1: 1 . The chemical analysis and texture of the soil showed: $\mathrm{pH}$ in water $=5,31 ; \mathrm{P}=3,77 \mathrm{mg} \mathrm{dm}^{3} ; \mathrm{K}^{+}=142,97 \mathrm{mg} \mathrm{dm}^{3}$ (Mehlich-1 extractor); $\mathrm{Ca}^{2+}=3,89 \mathrm{cmol}_{\mathrm{c}} \mathrm{dm}^{-3} ; \mathrm{Mg}^{2+}=1,88$ $\mathrm{cmol}_{\mathrm{c}} \mathrm{dm}^{-3} ; \mathrm{Al}=0,09 \mathrm{cmol}_{\mathrm{c}} \mathrm{dm}^{-3}\left(\mathrm{KCl} 1 \mathrm{~mol} \mathrm{~L}^{-1}\right.$ extractor$)$; Cation-exchange capacity $=9,95 \mathrm{cmol}_{\mathrm{c}} \mathrm{dm}^{-3}$; organic matter: 10 $\mathrm{g} \mathrm{kg}^{-1}$; sand $=250 \mathrm{~g} \mathrm{~kg}^{-10} \%$; silt $=240 \mathrm{~g} \mathrm{~kg}^{-1}$; clay $=510 \mathrm{~g} \mathrm{~kg}^{-1}$.

The coffee seeds were germinated in plastic trays containing washed sand under growing room conditions $\left(28^{\circ} \mathrm{C}\right.$ temperature, 12 hours photoperiod and 60 to $80 \%$ relative humidity). The humidity of the trays was maintained and periodic irrigations were made. When the seedlings reached the "matchstick" phase, that is, before the release of cotyledon leaves, they were transplanted to $50 \mathrm{~mL}$ tubes containing the aforementioned substrate. At the time of transplantation, the seedlings received $10 \mathrm{~g}$ of the inoculum containing the AMF $R$. Clarus (22 spores $\mathrm{g}^{-1}$ ), A. colombiana (33 spores $\mathrm{g}^{-1}$ ) next to the roots according to each treatment. $50 \%$ of each inoculum was used (5g R. clarus and $5 \mathrm{~g}$ A. colombiana). Phosphorus fertilization was not performed in the formation of seedlings in order to avoid possible inhibition of colonization due to fertilization of the substrate. Then the seedlings were taken to the vegetation house and daily irrigated manually.

When the plants reached 4 to 5 leaf pairs, at 150 days after transplanting, they were transplanted to PVC columns filled with dystrophic Red-Yellow Latosol (LVd) Embrapa, (2006), collected in the sieved 0-20 cm layer non-sterile (Table 1). The column was composed by the overlap of three rigid PVC rings, $100 \mathrm{~mm}$ in diameter and $0,10 \mathrm{~m}$ in height, joined by adhesive tape. The internal walls of the columns were covered with paraffin, in order to avoid the lateral flow of water. At the bottom of each column, a plastic plate was attached so that no soil loss occurred (Figure 1).

Fertilizer planting was carried out homogeneously in the $0-0,3 \mathrm{~m}$ layers, reducing the recommendation of $\mathrm{P}_{2} \mathrm{O}_{5}$ for coffee planting to $50 \%$, which was 50 g per pit $\left(64 \mathrm{dm}^{3}\right)$ Guimarães et al. (1999), the quantity being converted to the PVC column volume of $2.35 \mathrm{dm}^{3}$. After 45 days of planting, the fertilizer was covered with $5 \mathrm{~g}$ of $\mathrm{N}$ per plant using ammonium sulfate as source, according to the Minas Gerais Soil Fertility Commission Guimarães et al. (1999).

Table 1: Physical and chemical characteristics of dystrophic Red-Yellow Latosol used as substrate of $C$. arabica plants inoculated with AMF in PVC columns in a vegetation house.

\begin{tabular}{|c|c|c|c|c|c|c|c|c|c|}
\hline \multicolumn{10}{|c|}{ Chemical analysis } \\
\hline $\mathrm{pH}$ & $\mathrm{P}$ & $\mathrm{K}$ & $\mathrm{Al}$ & $\mathrm{Ca}$ & $\mathrm{Mg}$ & $\mathrm{T}$ & $\mathrm{V}$ & $\mathrm{m}$ & O.M \\
\hline Water & \multicolumn{2}{|c|}{$---m g d^{-3}--$} & \multicolumn{4}{|c|}{----cmolc $\mathrm{dm}^{-3}---$} & \multicolumn{2}{|c|}{$\%$} & $\mathrm{~g} \mathrm{~kg}^{-1}$ \\
\hline 5.97 & 32.73 & 262.36 & 0.02 & 5.03 & 2.38 & 10.89 & 74 & 0 & 33.6 \\
\hline \multicolumn{10}{|c|}{ Textural Analysis } \\
\hline \multicolumn{3}{|c|}{ Sand } & & \multicolumn{3}{|c|}{ Silt } & \multicolumn{3}{|c|}{ Clay } \\
\hline \multicolumn{10}{|c|}{ 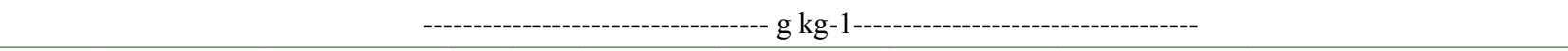 } \\
\hline \multicolumn{4}{|c|}{250} & \multicolumn{3}{|c|}{240} & \multicolumn{3}{|c|}{510} \\
\hline
\end{tabular}

$\mathrm{pH}$ in water: Soil-water ratio 1: 2.5. P and K: Mehlich-1 extractor. Ca, $\mathrm{Mg}$ and $\mathrm{Al}: 1 \mathrm{~mol} \mathrm{~L}{ }^{-1} \mathrm{KCl}$ extractor. T: Cation-exchange capacity. m: Aluminum saturation. V: Base saturation. O.M.: Organic matter determined by the Walkey \& Black method. 


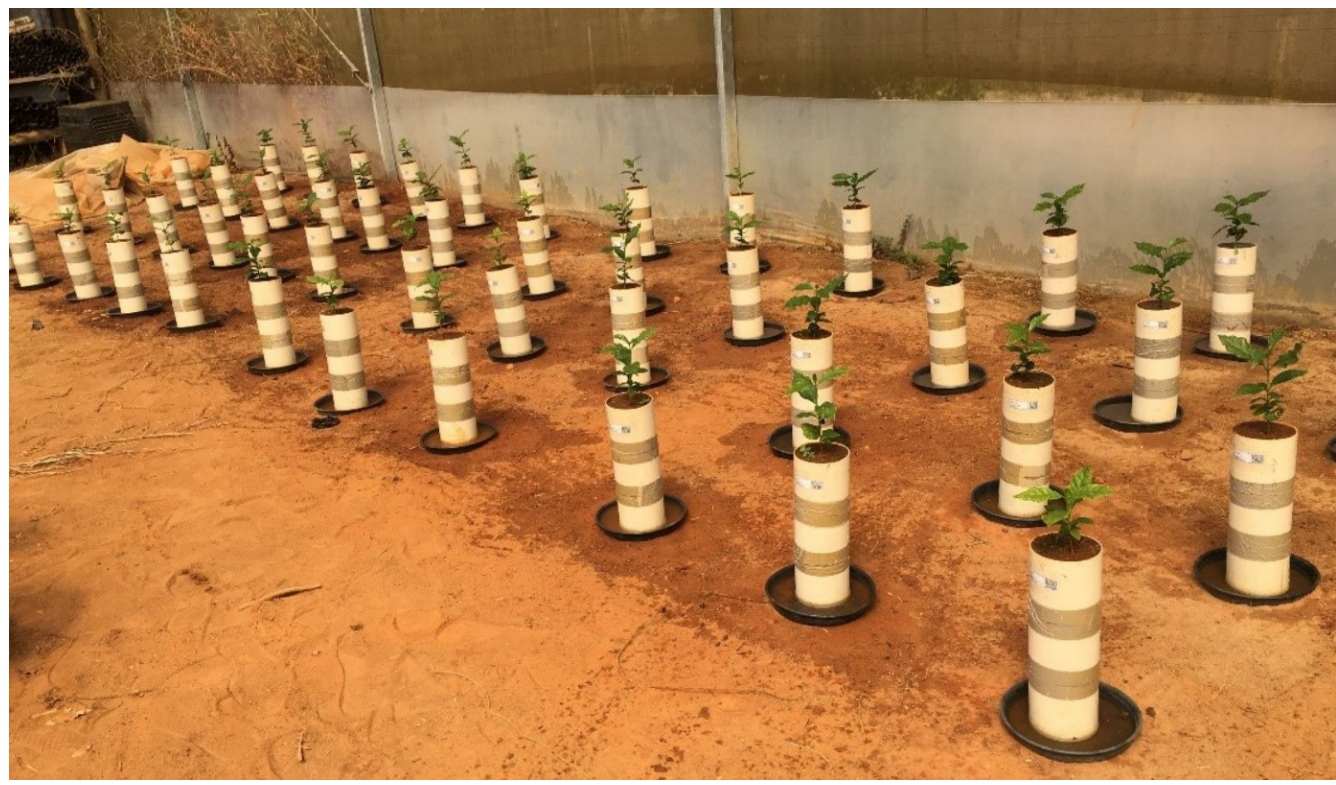

Figure 1: Coffee plant growth columns consisting of three overlapping rigid PVC rings.

The plants were irrigated daily, maintaining $80 \%$ of field capacity. Phytosanitary and weed management were performed manually when necessary.

At 150 days after planting, physiological characteristics were evaluated using an ADC infrared gas analyzer (IRGA), model LCA 4 (Analytical Development Co. Ltd, Hoddesdon, UK) in a vegetation house in last and fourth fully expanded leaves counted from the base of the plant. At this time, the following physiological characteristics were measured: photosynthetic rate $\mathrm{A}\left(\mu \mathrm{mol} \mathrm{m} \mathrm{m}^{-2} \mathrm{~s}^{-1}\right)$, substatic $\mathrm{CO}_{2}$ concentration $\mathrm{Ci}\left(\mu \mathrm{mol} \mathrm{mol}{ }^{-1}\right)$, consumed carbon rate $\Delta \mathrm{CO}_{2}$ $\left(\mu \mathrm{mol} \mathrm{mol}{ }^{-1}\right)$, stomatal conductance of water vapor Gs (mol $\left.\mathrm{m}^{-1} \mathrm{~s}^{-1}\right)$, sweating rate $\mathrm{E}\left(\mathrm{mol} \mathrm{H}_{2} \mathrm{O} \mathrm{m}^{-2} \mathrm{~s}^{-1}\right)$, water use efficiency WUE ( $\mathrm{mol} \mathrm{CO} \mathrm{CO}_{2} \mathrm{~mol} \mathrm{H}_{2} \mathrm{O}^{-1}=$ photosynthesis / transpiration ) and the ratio of internal carbon to atmospheric carbon $\mathrm{Ci} / \mathrm{Ca}$. The evaluation was carried out between 8 am and 10 am on a clear day with natural light, and the photosynthetically active photon flux density was fixed in the chamber of the apparatus to $1400 \mu \mathrm{mol} \mathrm{m} \mathrm{m}^{-2} \mathrm{~s}^{-1}$.

For the analysis of percentage of colonized roots length (percentage of colonization), samples of the root system were collected. Approximately $1 \mathrm{~g}$ of roots were taken from each layer (ring) of the experimental unit and stored in 50\% ethyl alcohol solution. until the moment of counting. The sampled roots were clarified with $10 \% \mathrm{KOH}$, acidified with $1 \% \mathrm{HCl}$ and stained with trypan blue in $0.05 \%$ lactoglycerol Phillips and Hayman (1970). The evaluation of mycorrhizal colonization was performed by the checkered plate intersection method under a stereomicroscope Giovannetti and Mosse (1980), counting at least 100 root segments. It was also performed the percentage of total colonization, obtained by summing the values found in each layer of the soil column.
Data were subjected to analysis of variance by the $F$ test $(\mathrm{p}<0.05)$, and when significant, means were compared by Tukey test at $5 \%$ significance level, with the aid of SISVAR 5.6 software. Correlation analysis between physiological parameters and percentage of root colonization was performed using Pearson's correlation coefficient (r), using the statistical program SIGMAPLOT version 12.0.

\section{RESULTS AND DISCUSSION}

The photosynthetic rate (A) of coffee plants was higher in AMF inoculated plants, regardless of inoculum and evaluated cultivars. These increases ranged from 216 to $233 \%$ for Rubi cultivar, 224.8 to $283.23 \%$ for Catuaí and from 194.94 to $251.27 \%$ for Mundo Novo compared to uninoculated plants (Table 2).

Some studies have shown that mycorrhizal symbiosis can alter the stomatal behavior and water Relations of host plants Augé, Toler and Saxton (2015), resulting in considerable increases in photosynthetic rate. In the present work there was no analysis of $\mathrm{P}$ content in leaf tissue, however, an increase in photosynthetic rate may be a result of increased P uptake by inoculated plants Amiri et al. (2017), since this element is one of the main photosynthetic process components, which is required for ATP production from ADP, P-triose production and export, and 1.5 bisphosphate (RuBP) ribulose regeneration Geiger and Servaites (1994). According to Yano-Melo et al. (1999), in banana plants inoculated with R. clarus and Gigaspora margarita, there were increases in photosynthetic rates and transpiration, in which such effect may have occurred due to higher phosphorus uptake by plants. 
Table 2: Photosynthetic rate (A), stomatal conductance (Gs) and transpiration (E) of Coffea arabica cultivars inoculated with arbuscular mycorrhizal fungi, kept in PVC columns and in a vegetation house at 150 days after transplantation.

\begin{tabular}{|c|c|c|c|c|c|}
\hline Cultivars & Control & R. clarus & A. colombiana & Mix & \\
\hline \multicolumn{5}{|c|}{$\mathrm{A}\left(\mu \mathrm{mol} \mathrm{m} \mathrm{m}^{-2} \mathrm{~s}^{-1}\right)$} & Mean \\
\hline Rubi & $1.80 \mathrm{Ab}$ & $5.69 \mathrm{Aa}$ & $5.03 \mathrm{Aa}$ & $6.00 \mathrm{Aa}$ & 4.63 \\
\hline Catuaí Vermelho & $1.61 \mathrm{Ab}$ & $6.17 \mathrm{Aa}$ & $5.23 \mathrm{Aa}$ & $5.95 \mathrm{Aa}$ & 4.74 \\
\hline Mundo Novo & $1.58 \mathrm{Ab}$ & $5.55 \mathrm{Aa}$ & 4.66 Aa & $5.26 \mathrm{Aa}$ & 4.26 \\
\hline Mean & 1.66 & 5.80 & 4.98 & 5.74 & \\
\hline CV $(\%)$ & & 11.38 & & & \\
\hline \multicolumn{5}{|c|}{ Gs $\left(\mu \mathrm{mol} \mathrm{m} \mathrm{m}^{-1} \mathrm{~s}^{-1}\right)$} & Mean \\
\hline Rubi & $0.02 \mathrm{Ac}$ & $0.09 \mathrm{Aa}$ & $0.06 \mathrm{Ab}$ & $0.08 \mathrm{Aab}$ & 0.06 \\
\hline Catuaí Vermelho & $0.03 \mathrm{Ab}$ & $0.08 \mathrm{Aa}$ & $0.05 \mathrm{Aa}$ & $0.08 \mathrm{Aa}$ & 0.06 \\
\hline Mundo Novo & $0.01 \mathrm{Ac}$ & $0.08 \mathrm{Aa}$ & $0.05 \mathrm{Ab}$ & $0.07 \mathrm{Aa}$ & 0.05 \\
\hline Mean & 0.02 & 0.08 & 0.05 & 0.08 & \\
\hline CV $(\%)$ & & 21.67 & & & \\
\hline \multicolumn{5}{|c|}{ 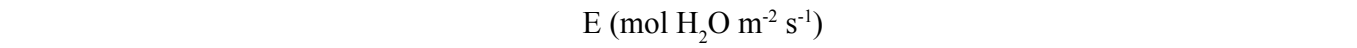 } & Mean \\
\hline Rubi & $0.54 \mathrm{Ac}$ & $1.56 \mathrm{Aa}$ & $1.10 \mathrm{Ab}$ & 1.25 Aab & 1.11 \\
\hline Catuaí Vermelho & $0.67 \mathrm{Ac}$ & $1.51 \mathrm{Aa}$ & $0.95 \mathrm{Abc}$ & $1.17 \mathrm{Ab}$ & 1.08 \\
\hline Mundo Novo & $0.24 \mathrm{Bb}$ & $1.22 \mathrm{Ba}$ & $0.90 \mathrm{Aa}$ & $1.05 \mathrm{Aa}$ & 0.85 \\
\hline Mean & 0.48 & 1.43 & 0.98 & 1.16 & \\
\hline CV $(\%)$ & & 16.29 & & & \\
\hline
\end{tabular}

Means followed by the same letter uppercase in the column and lowercase in the row do not differ from each other by the Tukey test at $5 \%$ probability. $R$. clarus = Rhizophagus clarus; . colombiana = Acaulospora colombiana; $\mathrm{Mix}=A$. colombiana $+R$. clarus.

In seedlings of Physalis peruviana L. cultivated under water stress, inoculation with AMF plants increased root dry mass, photosynthetic rate, stomatal conductance and transpiration, which served to alleviate the damage caused by water deficit Reys et al. (2019).

The higher photosynthetic rate in inoculated plants can also be based on the obligatory symbiosis, which demands from the plant part of the carbohydrates from its photosynthesis, and the total cost at which the fungus represents to the host plant can reach $20 \%$ of photosynthesis production. Adolfsson et al. (2015); Boldt et al. (2011). In response, there are increases in carbon uptake by plants to offset fungal demand and benefit from improved nutrition provided by FMA Adolfsson et al. (2015).

The stomatal conductance (Gs) showed no significant differences between cultivars, however, the responses of each cultivar varied as a function of the associated mycorrhizal fungus (Table 2). The cultivars Rubi and Mundo Novo had an increase in stomatal conductance by inoculation with AMF, with the highest values obtained with inoculation of $R$. clarus and Mix (Table 2). In these treatments there was an increase of 4.5 and 4 times respectively higher than the values of the control plants. For the Catuaí cultivar, it was observed that the inoculated plants obtained a mean increase in stomatal conductance of 2.3 times compared to control plants, regardless of the inoculum used (Table 2).

Higher stomatal conductance by AMF inoculation were also reported for melon culture, however, under saline stress, where AMF inoculated plants presented higher Gs value when compared to uninoculated plants at all salinity levels Lúcio et al. (2013).

Symbiosis with AMF can cause changes in plant hormone levels, stimulating its production, with consequent changes in stomatal conductance Augé, Toler and Saxton, (2015).Among phytohormones, auxins, cytokines, gibberellins, ethylene, abscisic acid, jasmonic acid and salicylic acid may act to control the development of mycorrhizal symbiosis, but the mechanisms are not well understood Lambais (2006), Kiriachek et al. (2009). This means that under normal cultivation conditions, ie with sufficient water and nutrients, arbuscular mycorrhizal fungi regulate the stomatal opening more efficiently, keeping their stomata open longer, which allows the plant greater input of $\mathrm{CO}_{2}$, resulting in increasing photosynthetic rates Birhane et al. (2012).

Similar behavior to stomatal conductance was also observed for the perspiration rate (E) of coffee plants (Table 2). The cultivars Rubi and Catuaí had significant increase with the inoculation of $R$. clarus and Mix, these increases were 188.9 and 
$131.5 \%$ respectively for Rubi plants and 125.3 and $74.3 \%$ for plants. of Catuaí, when compared to the control. For Mundo Novo, regardless of the inoculum used, the inoculated plants presented higher transpiratory rates than the control ones (Table 2).

Because AMF affect photosynthesis and leaf water potential, they indirectly influence stomata opening and, therefore, stomatal transpiration. Augé, Toler and Saxton (2015); Quiroga et al. (2017). Plants grown with adequate mineral supply also have higher stomatal conductance. In this sense, the better plant nutrition provided by the AMF possibly reflected in greater stomatal opening.

Some studies have shown positive responses of AMF contribution on physiological parameters for some plant species, such as melon (Cucumis melo L.) and Phisalis (Physalis peruviana L.) Lúcio et al. (2013), Reys et al. (2019). In coffee plants (Coffea arabica L.) there are no studies that relate physiological aspects and AMF inoculation, and most studies were conducted under water or saline stress conditions.

Among coffee cultivars, it was found that the highest value for transpiratory rate (E) was observed for Rubi and Catuaí cultivars inoculated with $R$. clarus and for control (Table 2).

The consumed carbon $\left(\Delta \mathrm{CO}_{2}\right)$ of coffee plants was significantly increased with AMF inoculation, with higher values provided by $R$. clarus inoculation in all evaluated cultivars, which was accompanied by the decrease of internal carbon concentration (Ci). same treatment (Table 3).

Thus, where the photosynthetic rate is higher, the $\mathrm{CO}_{2}$ concentration tends to be lower. The $\mathrm{CO}_{2}$ consumed is directly related to the photosynthetic intensity of the plant, that is, the higher the photosynthetic rate, the faster the $\mathrm{CO}_{2}$ is consumed, and the lower its concentration inside the leaf Silveira et al (2012).

Comparing the cultivars, it appears that the cultivar Mundo Novo consumed more $\mathrm{CO}_{2}$ when inoculated with $R$. clarus, but did not reflect lower internal $\mathrm{CO}_{2}(\mathrm{Ci})$ concentration in leaf mesophyll and higher photosynthetic activity (A) (Table 2) than the other cultivars in the same treatment. The faster the plant metabolism, the higher the $\Delta \mathrm{CO}_{2}$ per unit of time Galon et al. (2010).

Regarding water use efficiency (WUE), it was observed that for Rubi cultivar, there was a significant increase with Mix inoculation, with a maximum value of $5.04 \mu \mathrm{mol} \mathrm{CO}_{2} \mathrm{~mol}^{-1}$ $\mathrm{H}_{2} \mathrm{O}$. For Catuaí, the inoculated plants were larger than the uninoculated ones, regardless of the inoculum used (Table 3). While Mundo Novo cultivar did not increase US with FMA inoculation. Regarding water use efficiency (WUE), it was observed that for Rubi cultivar there was significant increase

Table 3: Carbon consumed $\left(\Delta \mathrm{CO}_{2}\right)$, internal carbon $(\mathrm{Ci})$ and internal carbon/atmospheric carbon ( $\left.\mathrm{Ci} / \mathrm{Ca}\right)$ ratio and water use efficiency (EUA) of Coffea arabica L. cultivars, inoculated with arbuscular mycorrhizal fungi, maintained in columns of PVC and in a vegetation house at 150 days after transplanting.

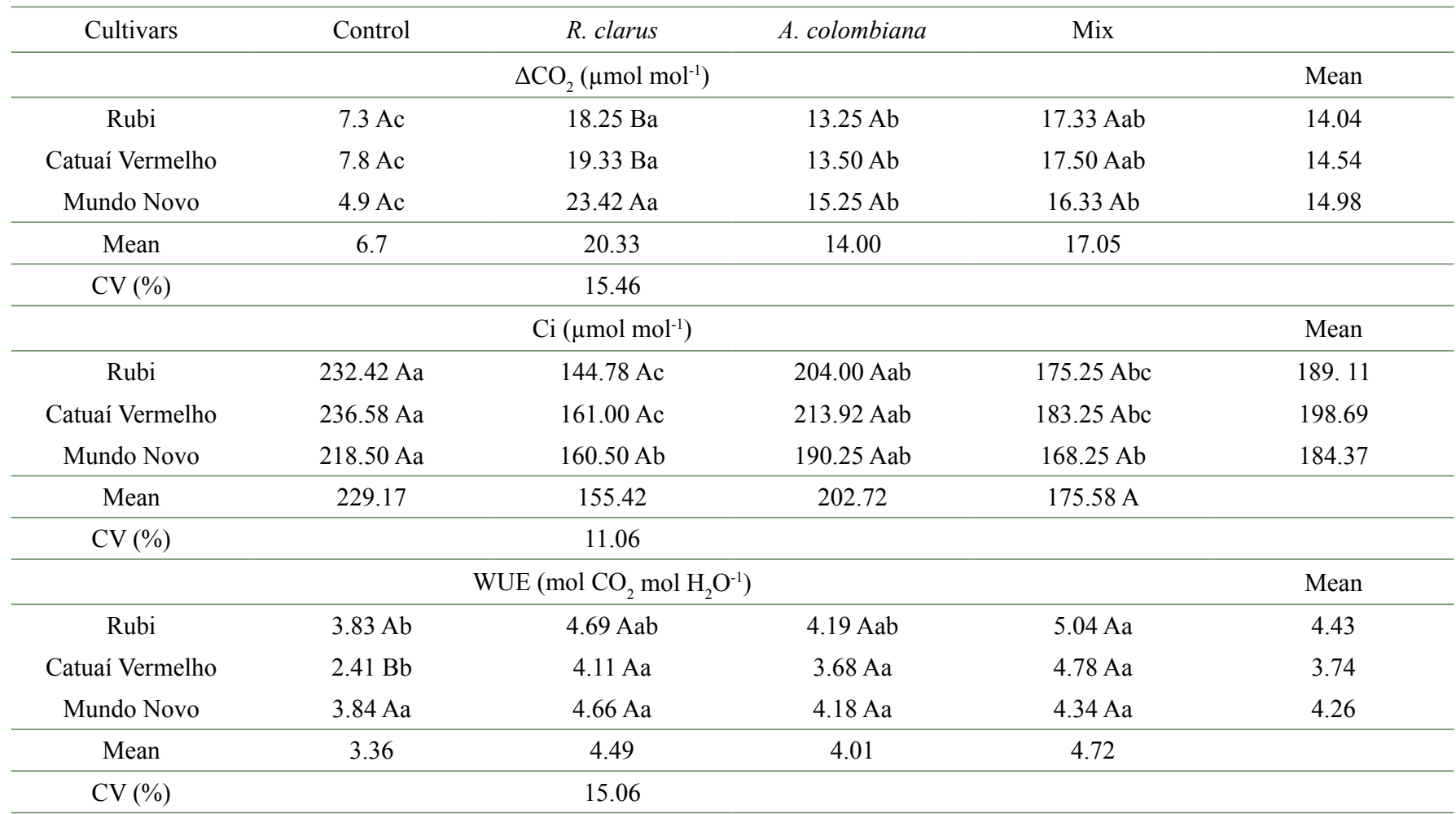

Means followed by the same letter uppercase in the column and lowercase in the row do not differ from each other by the Tukey test at $5 \%$ probability. $R$. clarus $=$ Rhizophagus clarus; $A$. colombiana $=$ Acaulospora colombiana; Mix $=$ A. colombiana $+R$. clarus. 
with Mix inoculation, with maximum value. of $5.04 \mu \mathrm{mol} \mathrm{CO}_{2}$ $\mathrm{mol}^{-1} \mathrm{H}_{2} \mathrm{O}$. For Catuaí, the inoculated plants were larger than the uninoculated ones, regardless of the inoculum used (Table 3). While the cultivar Mundo Novo did not increase from the WUE with the inoculation of AMF.

Water use efficiency (WUE) relates the amount of carbon the plant fixes per unit of water it loses Jaimez et al. (2005). Thus, greater efficiency in water use indicates that the plant can produce more dry matter per gram of water transpired Faustino et al. (2017). In general, the Gs values (Table 2) presented by AMF-inoculated coffee plants follow the $\mathrm{CO}_{2}$ assimilation and transpiration values. Therefore, it is suggested that plants in association with AMF are more efficient in stomatal regulation than non-mycorrhized ones. Similar results to this study were observed for Allium cepa species, in which plants inoculated with different AMF species showed higher water use efficiency compared to uninoculated ones Bolandnazar et al. (2007).

Regarding the comparisons between cultivars, it was observed different behaviors between them, only in the control treatment, in which the cultivars Rubi and Mundo Novo showed greater efficiency in water use compared to Catuaí Vermelho, however for this cultivar there was no effect of inoculation. mycorrhizal disease (Table 3). This behavior can be explained by the lower transpiratory rate of these plants in relation to the other cultivars (Table 3 ), which consequently reflected in higher water use efficiency values, since this parameter is given by the ratio between the photosynthetic rate and the perspiration.

The total percentage of colonized roots was influenced $(p<0.05)$ by AMF species, and this effect was dependent on cultivar (Table 4).

Mycorrhizal colonization was higher in inoculated plants compared to uninoculated plants in all cultivars, and the highest rates of Rubi and Catuaí cultivars were higher in Mix treatment, which were higher in relation to the others, and for Mundo cultivar. New, regardless of AMF species, inoculation provided greater colonization than uninoculated plants (Table 5). This result justifies the higher photosynthetic rates, transpiration and stomatal conductance observed for plants that received some kind of inoculation, since plants in symbiosis with AMFs usually have higher photosynthetic and transpiratory rates due to higher water absorption per unit length. root Adolfsson et al. (2015).

Correlation analysis showed that photosynthetic rate (A), stomatal conductance (Gs), perspiration (E), carbon

Table 4: Percentage of mycorrhizal colonization of Coffea arabica L. cultivars inoculated with arbuscular mycorrhizal fungi at 150 days after planting.

\begin{tabular}{|c|c|c|c|c|c|}
\hline \multirow{2}{*}{ Cultivars } & \multicolumn{4}{|c|}{ Arbuscular mycorrhizal fungi } & \multirow[b]{3}{*}{ Mean } \\
\hline & Sem FMA & R. clarus & A. colombiana & Mix & \\
\hline & \multicolumn{4}{|c|}{--------\% Colonization -------- } & \\
\hline Rubi & $13.3 \mathrm{ABd}$ & $57.5 \mathrm{Ab}$ & $24.4 \mathrm{Cc}$ & $65.98 \mathrm{Aa}$ & 41.0 \\
\hline Catuaí Vermelho & $10.0 \mathrm{Bc}$ & $40.0 \mathrm{Bb}$ & $44.8 \mathrm{Ab}$ & $57.7 \mathrm{Ba}$ & 38.1 \\
\hline Mundo Novo & $14.9 \mathrm{Ab}$ & $36.3 \mathrm{Ba}$ & $35.6 \mathrm{Ba}$ & $38.9 \mathrm{Ca}$ & 31.4 \\
\hline Mean & 12.7 & 44.62 & 35.95 & 54.22 & \\
\hline
\end{tabular}

Means followed by the same letter uppercase in the column and lowercase in the row do not differ from each other by the Tukey test at $5 \%$ probability. $R$. clarus $=$ Rhizophagus clarus; . colombiana $=$ Acaulospora colombiana; Mix $=A$. colombiana $+R$. clarus.

Tabela 5: Pearson correlation coefficients ( $r$ ) estimated between mycorrhizal colonization (\%) with photosynthetic rate (A), stomatal conductance $(\mathrm{Gs})$, internal carbon concentration $(\mathrm{Ci})$, transpiration rate $(\mathrm{E})$, carbon consumed $(\Delta \mathrm{CO} 2)$ and water use efficiency (WUE) of Coffea arabica L. cultivars.

\begin{tabular}{cll}
\hline Variáveis & Valor (r) & P valor \\
\hline $\mathrm{A}$ & $0.834^{* *}$ & 0.0000 \\
$\mathrm{Gs}$ & $0.770^{* *}$ & 0.0000 \\
$\mathrm{Ci}$ & $-0.602^{* *}$ & 0.0000 \\
$\mathrm{E}$ & $0.724^{* *}$ & 0.0000 \\
$\Delta \mathrm{CO}_{2}$ & $0.694^{* *}$ & 0.0000 \\
$\mathrm{WUE}$ & $0.600^{* *}$ & 0.0000 \\
\hline
\end{tabular}

$(* *)$ significant at $1 \%$ probability by the "t" test. 
consumed $(\triangle \mathrm{CO} 2)$ and water use efficiency (QUE) correlated positively and significantly with the percentage of root colonization, while the internal carbon concentration (Ci) correlated negatively (Table 5).

This result shows that the change in physiological variables was related to the formation of mycorrhizal association and its benefits. Several studies report significant correlations between growth parameters, nutrient content and percentage of colonization, as in sweet passion fruit plants Vitorazi Filho et al. (2012), melon seedlings Silva Júnior et al (2012) and cedar seedlings. Australian Silva et al. (2017). However, for the coffee crop (Coffea arabica) there are no studies in the literature demonstrating the correlation and efficiency of mycorrhizal symbiosis on physiological parameters, a fact observed in the present study.

\section{CONCLUSIONS}

AMF inoculation affected the physiology of coffee plants, increasing photosynthetic rate $(\mathrm{A})$, stomatal conductance (Gs), transpiration, carbon consumed $\left(\Delta \mathrm{CO}_{2}\right)$, water use efficiency (EUA) and percentage of mycorrhizal colonization $(\%)$, as well as reducing the internal carbon concentration (Ci) for all AMF cultivars and species combinations.

The $R$. clarus species and the mixed inoculum $(R$. clarus $+A$. colombiana) were more efficient in increasing the physiological variables for all evaluated cultivars.

\section{ACKNOWLEDGEMENTS}

The authors would like to thank University Federal of Vales do Jequitinhonha and Mucuri - UFVJM for the support in the conduction of this study.

\section{REFERENCES}

ADOLFSSON, L. et al. Mycorrhiza symbiosis increases the surface for sunlight capture in Medicago truncatula for better photosynthetic production. Plos One, 10(1):1-18, 2015.

AMIRI, R. et al. Variation in the essential oil composition, antioxidant capacity, and physiological characteristics of Pelargonium graveolens L. inoculated with two species of mycorrhizal fungi under water deficit conditions. Journal of Plant Growth Regulation, 36(2):502-515, 2017.

AUGÉ, R.; TOLER, H.; SAXTON, A. Arbuscular mycorrhizal symbiosis alters stomatal conductance of host plants more under drought than under amply watered conditions: a meta-analysis. Mycorrhiza, 25(1):13-24, 2015.

BAGYARAJ, D. J.; SHARMA, M. P.; MAITI, D. Phosphorus nutrition of crops through arbuscular mycorrhizal fungi. Current Science, 108(7):1288-1293, 2015.
BIRHANE, E. et al. Arbuscular mycorrhizal fungi enhance photosynthesis, water use efficiency, and growth of frankincense seedlings under pulsed water availability conditions. Oecologia, 169(4):895-904, 2012.

BOLANDNAZAR, S. et al. Mycorrhizal colonization improves onion (Allium cepa L.) yield and water use efficiency under water deficit condition. Scientia Horticulturae, 114(1):11-15, 2007.

BOLDT, K. et al. Photochemical processes carbon assimilation and RNA accumulation of sucrose transporter genes in tomato arbuscular mycorrhiza. Journal of Plant Physiology, 168(11):1256-1263, 2011.

\section{EMPRESA BRASILEIRA DE PESQUISA AGROPECUÁRIA} - EMBRAPA. Sistema Brasileiro de Classificação de Solos. 2.ed. Rio de Janeiro, 2006, 306p.

FAUSTINO, L. A. et al. Aspectos físiológicos de plantas de eucalipto em convivência com Commelina benghalensis. Revista Espacios, 38(42):5, 2017.

FRANÇA, A. C. et al. Mycorrhizal fungi increase coffee plants competitiveness against Bidens pilosa interference. Pesquisa Agropecuária Tropical, 46(2):132-139, 2016.

GEIGER D.R.; SERVAITES, J. C. Diurnal regulation of photosynthetic carbon metabolism in c3 plants. Annual review of Revista Annual review of plant physiology and plant molecular biology (Online), 45(1):235-256, 1994. Disponível em: <https:/www.annualreviews.org/doi/ pdf/10.1146/annurev.pp.45.060194.001315> Acesso em: 13 de setembro de 2019.

GALON, L. et al. Tolerância de novos genótipos de cana-de açúcar a herbicidas. Planta Daninha, 28(2):329-338, 2010 .

GERDEMANN, J. W.; NICOLSON, T. H. Spores of mycorrhizal endogone species extracted from soil by wet sieving and decanting. Transactions of the British Mycological Society, 46(2):235-244, 1963.

GIOVANETTI, M.; MOSSE, B. An evaluation of techniques for measuring vesicular arbuscular mycorrhizal infection in roots. New Phytologist, 84:489-500, 1980.

GUIMARÃES, P. T. G. et al. Cafeeiro. In: RIBEIRO, A. C.; GUIMARÃES, P. T. G.; ALVAREZ, V. V. H. (Eds). Recomendação para o uso de corretivos e fertilizantes em Minas Gerais: 5a aproximação. Viçosa: Comissão de Fertilidade do Solo do Estado de Minas Gerais, 1999. p. 289-302. 
HEIJDEN, M. G. et al. Mycorrhizal ecology and evolution: the past, the present, and the future. New Phytologist, 205(4):1406-1423, 2015.

JAIMEZ, R. E. et al. A. Seasonal variations in leaf gas exchange of platain cv. 'Hartón' (Musa AAB) under different soil water conditions in a humid tropical region. Scientia Horticulturae, 104(1):79-89, 2005.

KIRIACHEK, S. G. et al. Regulation of arbuscular mycorrhizae development. Revista Brasileira Ciência do Solo, 33(1):1-16, 2009.

LAMBAIS, M. R. Unraveling the signaling and signal transduction mechanisms controlling arbuscular mycorrhiza development. Scientia Agricola, 63(4):405413, 2006.

LÚCIO W. S. et al. Crescimento e respostas fisiológicas do meloeiro inoculado com fungos micorrízicos arbusculares sob estresse salino. Semina, 34(4):15871602, 2013.

MACHINESKI, G. S. et al. Effects of arbuscular mycorrhizal fungi on early development of persimmon seedlings. Folia Horticulturae, 30(1):39-46, 2018.

MIRSHAD, P.; PUTHUR, J. Drought tolerance of bioenergy grass Saccharum spontaneum L. enhanced by arbuscular mycorrhizae. Rhizosphere, 3(1):1-8, 2017.

MOREIRA, S. D. et al. Inoculation with mycorrhizal fungi on the growth and tolerance to water deficit of coffee plants. Revista Brasileira de Engenharia Agrícola e Ambiental, 22(11):747-752, 2018.

MUSTAFA, G. et al. O fornecimento de fósforo, as espécies de fungos micorrízicos arbusculares e o impacto do genótipo da planta na eficácia protetora da inoculação micorrízica contra o oídio em pó. Micorriza, 26(7):685697, 2016.

PEDRO, F. C. et al. Comportamento agronômico de progênies $\mathrm{F} 4$ de cafeeiros oriundos do cruzamento entre os cultivares Mundo Novo e Catuaí. Revista Ceres, 58(3):315-322, 2011.

PHILLIPS, J. M.; HAYMAN, D. S. Improved procedures for cleaning roots and staining parasitic and vesiculararbuscular mycorrhizal fungi for rapid assessment of infection. Transactions of the British Mycological Society, London, 55(1):158-161, 1970.

PINHEIRO, A. C. T.; SOUZA, L. T. O.; COIMBRA, J. L. Controle de Meloidogyne enterolobii em mudas de goiabeira com fungos micorrízicos isolados do Cerrado baiano. Revista Agro@mbiente On-line, 8(3):398-403, 2014.
QUIROGA, G. et al. Enhanced drought stress tolerance by the arbuscular mycorrhizal symbiosis in a droughtsensitive maize cultivar is related to a broader and differential regulation of host plant aquaporins than in a drought-tolerant cultivar. Frontiers in Plant Science, 8(1):1056, 2017.

REYES, S. M. R. et al. Physiological response of Physalis peruviana L. seedlings inoculated with Funneliformis mosseaeunder drought stress. Revista de Ciências Agrárias, 42(1):175-183, 2019.

SIQUEIRA, J. O.; COLOZZI-FILHO, A. Micorrizas vesículo-arbusculares em mudas de cafeeiro. II. Efeito do fósforo no estabelecimento e funcionamento da simbiose. Revista Brasileira de Ciência do Solo, 10(3): 207-211 1986.

SILVA JÚNIOR, J. M. T. et al. Efeito da esterilização do substrato sobre o crescimento de mudas de meloeiro em presença de fungos micorrízicos arbusculares e compostos orgânicos. Revista Caatinga, 25(1):98-103, 2012.

SILVA, E. P. et al. Micorrizas arbusculares e fosfato no desenvolvimento de mudas de cedro-australiano. Ciência Florestal, 27(4):1269-1281 2017.

SILVEIRA, H. M. et al. Características fotossintéticas de cultivares de mandioca tratadas com fluazifop-p-butyl e fomesafen. Revista Agro@ mbiente On-line, 6(3):222$227,2012$.

SOUSA, C. S. et al. Fungos micorrízicos arbusculares no controle de Meloidogyne incognita em mudas de tomateiro. Revista Caatinga, 23(1):15-20, 2010.

VITORAZI FILHO, J. A. et al. Crescimento de mudas de maracujazeiro-doce inoculadas com fungos micorrízicos arbusculares e bactérias diazotróficas sob diferentes doses de fósforo. Revista Brasileira de Fruticultura, 34(2):442-450, 2012.

YANO-MELO, A. M. et al. Effect of arbuscular mycorrhizal fungi on the acclimatization of micropropagated banana plantlets. Mycorrhiza, 9(2):129-133, 1999.

ZHAO, R. et al. Arbuscular mycorrhizal fungi affect the growth, nutrient uptake and water status of maize (Zea mays L.) grown in two types of coal mine spoils under drought stress. Applied Soil Ecology, 88(1):41-49, 2015.

ZHOU, Q. et al. Changes in carbon and nitrogen allocation, growth and grain yield induced by arbuscular mycorrhizal fungi in wheat (Triticum aestivum L.) subjected to a period of water deficit. Plant Growth Regulation, 75(3):751-760, 2015. 